\title{
GOSIP, HOAKS, DAN PEREMPUAN: REPRESENTASI DAN RESEPSI KHALAYAK TERHADAP FILM PENDEK "TILIK"
}

\author{
Putu Nur Ayomi \\ Program Studi Sastra Inggris, Fakultas Bahasa Asing \\ Universitas Mahasaraswati Denpasar \\ Jalan Kamboja No. 11A, Denpasar \\ No Hp.: +6285239649779, E-mail: putu.nur.a@unmas.ac.id
}

\begin{abstract}
ABSTRAK
Tulisan ini bertujuan untuk mengkaji bagaimana film "Tilik" sebagai film pendek Indonesia yang mendapat antusiasme sangat besar dari khalayak merepresentasikan pesan-pesan utama seperti gosip, hoaks, dan perempuan melalui beragam kode di dalam film tersebut. Kajian ini juga secara kualitatif membahas bagaimana resepsi dari khalayak dengan menggunakan teori representasi dan resepsi dari Stuart Hall. Selain analisis representasi yang menggunakan data dari film, digunakan pula data resepsi khalayak yang diperoleh dari komentar-komentar pengguna media sosial Twitter yang memiliki jumlah "suka" besar yang didapat dari hasil analisis data dari Drone Emprit, analis big data media sosial. Tulisan ini menunjukkan bahwa representasi pada film "Tilik" mengenai tema-tema di atas dapat dilihat secara denotatif dan konotatif. Dari segi resepsi, film "Tilik" dimaknai khalayak dari tiga posisi, yakni dominan, oposisional, dan negosiatif. Walaupun film "Tilik" dikritik sebagai film yang tidak edukatif terutama mengenai hoaks dan bias patriarkis, film ini mendapatkan pembacaan dominan sebagai film yang merepresentasikan realitas masyarakat Indonesia.
\end{abstract}

Kata kunci: gosip, perempuan, representasi, resepsi

\begin{abstract}
Gossip, Hoax, and Woman: The Representation and the Reception of the Audiences towards the Short Film "Tilik". This paper aims to examine how Tilik, an Indonesian short film that has received enormous enthusiasm from the audiences, represents some key messages such as gossip, hoaxes, and women through various codes in the film. This study also qualitatively discusses how the audiences perceive the film's messages by applying theory of representation and reception from Stuart Hall. Besides working on the analysis of representations using data from the film, audience reception data were obtained from the tweets of Twitter social media users which had many "likes" obtained from the data analysis of Drone Emprit, a social media big data analyst. The result showed that Tilik's representation of above themes can be seen denotatively and connotatively. From the perspective of audience reception, the film was interpreted from three positions: dominant, oppositional, and negotiated. Although the movie was criticized as a noneducational film, especially regarding hoaxes and patriarchal bias, this film received a dominant reading as a film that represents the reality of Indonesian society.
\end{abstract}

Keywords: gossip, woman, representation, reception 


\section{PENDAHULUAN}

Di tengah kekhawatiran banyak pihak akan lesunya film nasional, terdapat berita menggembirakan dari sebuah film pendek karya sineas muda Indonesia Wahyu Agung Prasetyo yang berjudul "Tilik" 'Menjenguk'. Film ini mendapatkan apresiasi dari banyak pihak bahkan menjadi trending topik di media sosial terutama Twitter. Tagar \#Tilik telah mendapat puluhan ribu cuitan dan dibahas dalam berbagai tagar baru hingga tiga hari sejak penayangan luas perdananya di Youtube pada 17 Agustus 2020 lalu. Hingga 20 Januari 202, film pendek tersebut telah disaksikan lebih dari 25 juta kali. Hal ini bukan sesuatu yang biasa untuk karya film pendek sineas Indonesia. Salah satu tokoh utamanya, Bu Tejo, serta beberapa kutipan percakapannya bahkan segera menjadi sumber meme dan stiker lawakan yang beredar di media sosial.

Film berbahasa Jawa yang berdurasi tiga puluh dua menit ini disponsori pembuatannya oleh Dinas Kebudayaan dan Pariwisata Pemprov Daerah Istimewa Yogyakarta. "Tilik" sebenarnya telah dirilis sejak 2018 silam serta telah memenangkan beberapa penghargaan lokal dan nasional. Film "Tilik" menjadi menarik karena mengangkat kebiasaan lokal masyarakat Jawa dan Indonesia pada umumnya, yakni beramai-ramai menjenguk kerabat atau teman yang sakit. Film ini juga dikemas dengan dialog bahasa Jawa sehari-hari yang lugas dan segar. Alur cerita dalam film ini berpusat pada perjalanan sekelompok perempuan dari sebuah desa ke kota di Yogyakarta untuk menjenguk $\mathrm{Bu}$ Lurah yang sakit dengan menumpang sebuah truk bak terbuka. Menurut sang sutradara, film tersebut terinspirasi dari praktik tilik warga Dlingo, Bantul, Yogyakarta yang memang terbiasa dilakukan dengan naik truk (Damarjati, 2020). Truk bak terbuka inilah yang kemudian menjadi panggung dari kegiatan bergosip para tokohnya dan menjadi inti cerita dalam film ini. Objek utama dari pergunjingan tersebut adalah tokoh Dian, seorang perempuan muda kembang desa yang dituduh melakukan "pekerjaan tidak benar".
"Tilik" mendapatkan banyak apresiasi dari berbagai kalangan. Banyak yang menyatakan bahwa tema yang diangkat dalam film ini begitu "relatable" (sangat terkait dengan realita keseharian masyarakat). Tokoh dan kejadian dalam film begitu membumi dan akrab dengan keseharian penonton. Beberapa pujian mengatakan bahwa film ini lucu, menghibur, dan mengangkat nilai tradisional Indonesia, yakni persaudaraan yang kental antarwarga desa yang ditandai dengan kegiatan tilik. Selain pujian, banyak pula kritik tajam yang ditujukan terhadap film ini. Kritik terbesar terutama datang dari perspektif feminis yang melihat bahwa film ini melanggengkan dan memperkuat stereotip-stereotip perempuan, tanpa ada usaha pembongkaran dan edukasi. Perdebatan antara yang memuji dan mengkritik film "Tilik" kian berlanjut antara dua kubu, yakni yang memandang film sebagai hiburan dan representasi kenyataan serta perspektif kedua yang memandang karya film memiliki fungsi lain selain hiburan. Film dapat menjadi alat hegemoni, tetapi sekaligus dapat menjadi alat perubahan sosial. Dalam hal tersebut, tulisan ini mencoba menjembatani perdebatan dari kedua perspektif itu dengan melihat film "Tilik" dari dua sisi, yakni konsep representasi dan resepsi dari Hall (1980; 1997).

Representasi mengacu pada bagaimana pemaknaan akan dunia disampaikan dalam tandatanda atau kode-kode material, misalnya bahasa, gambar, dan musik. Tidak ada makna yang tetap dan pasti dalam suatu tanda dan tidak mungkin bagi siapa pun untuk menyampaikan suatu realitas secara menyeluruh, maka setiap proses representasi adalah proses pemilihan, penciptaan, dan produksi makna. Representasi adalah proses penting dalam setiap peristiwa pertukaran makna dalam masyarakat. Bagaimana sesuatu tersebut digambarkan dan seperti apa gambaran tersebut adalah proses konstruksi budaya (Hall, 1997).

Saat ini, kekuasaan dalam penciptaan makna dimiliki oleh media massa, tokoh-tokoh berpengaruh, dan kekuatan-kekuatan ideologis lain yang memiliki akses besar kepada khalayak, 
termasuk film. Semakin populer suatu film, semakin besarlah kekuatan representasi dari film tersebut. Dalam proses representasi, pengulanganpengulangan akan suatu stereotip tanpa adanya ruang bagi representasi alternatif akan menciptakan persepsi masyarakat yang sempit dan kaku. Hal tersebut dapat memperkuat dan melanggengkan hegemoni yang ada di masyarakat yang menguntungkan suatu pihak dan merugikan pihak lainnya. Dengan demikian, Hall (1997) menyatakan pentingnya mempertanyakan suatu representasi yang disodorkan media.

Selain representasi, terdapat pula teori resepsi yang menekankan pada bagaimana khalayak menerima pesan dalam sebuah teks. Khalayak akan menginterpretasi sebuah teks berdasarkan nilai-nilai budaya yang ia miliki, pengalaman, dan cakrawala pengetahuannya. Terdapat tiga posisi khalayak dalam pemaknaan atau pembacaan suatu teks, yakni pemaknaan dominan 'dominant reading', pemaknaan oposisional 'opposition reading', dan pembacaan negosiatif 'negotiated reading' (Hall, 1980). Pada pemaknaan dominan, khalayak mengambil pembacaan yang sama seperti yang diharapkan pembuat teks. Hal ini terjadi ketika pesan teks yang direalisasikan melalui tandatanda semiotik dapat ditangkap dengan jelas oleh khalayak dan terdapat kesesuaian antara narasi yang disampaikan dengan latar belakang khalayak. Posisi kedua adalah posisi oposisi ketika khalayak menolak interpretasi dominan dan membuat pemaknaan sendiri akan sebuah teks. Hal tersebut dapat terjadi terutama pada isu-isu yang kontroversial, juga saat terdapat ketidaksesuaian antara pandangan pembuat teks dan latar belakang khalayak. Posisi ketiga adalah pemaknaan negosiatif yang berada dalam kompromi antara pemaknaan dominan dan pemaknaan oposisi. Dalam posisi ini, khalayak menerima sebagian narasi pembuat teks, tetapi memiliki pandangan yang berbeda pada pembacaan beberapa bagian teks. Tentu saja proses penciptaan makna (encode) dan pemaknaannya (decode) bukanlah sesuatu yang linier dan terputus. Resepsi sendiri, terutama yang disampaikan kepada khalayak lain, adalah bentuk pemaknaan sekaligus penciptaan makna yang terjadi secara terus-menerus.

Beberapa studi telah mengkaji representasi dalam film Indonesia mengenai beberapa isu misalnya perjuangan hidup perempuan, identitas etnis Tionghoa, dan nilai-nilai seperti persahabatan, pendidikan, dan perdamaian (Handayani, dkk., 2013; Manesah, 2016; Rokhani, dkk., 2016; Wahyuni E, 2020). Representasi ini dikaji dari teori semiotika Barthes, Pierce, dan Fiske, yakni bagaimana kode atau tanda menyampaikan pesanpesan tertentu, termasuk kode-kode sinematografi (Langga, Ahmad, \& Mansoor, 2020; Widiyatmika dkk., 2019). Mengenai resepsi khalayak di berbagai media dengan teori dari Hall, terdapat kajian dari (Agistian dkk., 2018 \& Pertiwi dkk., 2020) yang menggunakan metode wawancara dan kuesioner. Kajian ini berbeda karena melihat dari dua sisi, yaitu representasi dan resepsi. Selain itu, sumber data tentang resepsi dalam penelitian ini diperoleh dari pendapat pengguna media sosial Twitter.

Kajian ini adalah kajian kualiatatif yang dilakukan untuk menggambarkan representasi pesan-pesan dalam film dan resepsi khalayak terhadap film tersebut sehubungan dengan gosip, fitnah, hoaks, dan perempuan. Untuk menelaah representasi perlu dilakukan interpretasi tandatanda semiotik pada film yang dalam kajian ini menyangkut bahasa, pilihan alur cerita, dan aksi para pemeran film serta tanda-tanda simbolis lainnya. Untuk itu, digunakan teori semiotika Barthes (1998) mengenai makna denotatif dan konotatif. Makna denotasi adalah makna awal dari sebuah tanda yang menjadi rujukan pertama pemaknaan, misalnya awan gelap bermakna hujan akan segera datang. Makna konotasi adalah makna yang muncul pada tahapan pemaknaan berikutnya, yaitu interaksi antara tanda dan emosi pengguna, nilai-nilai kultural, dan pengalaman bersama suatu masyarakat pengguna tanda-tanda tersebut. Pada pemaknaan konotasi, awan gelap dapat bermakna kesedihan atau kehancuran. Makna pada tataran konotatif sifatnya lebih multitafsir dibandingkan pada tataran denotatif. 
Resepsi penonton dikaji secara semietnografis, yaitu dengan membahas tanggapan pengguna Twitter sebagai sumber data, terutama perbincangan pada akun-akun dengan jumlah interaksi tinggi, yakni jumlah komentar, retweet, dan terutama suka terbanyak. Pemilihan data dilakukan berdasarkan hasil analisis Drone Emprit, yakni analis media sosial berbasis big data yang dapat memetakan sentimen, emosi, dan demografi dari suatu isu di media sosial (lihat Suharso, 2019).

\section{REPRESENTASI DALAM FILM "TILIK"}

Di bagian ini akan dibahas mengenai representasi dari berbagai tema penting dalam film terutama yang terkait dengan gosip, hoaks, fitnah, dan perempuan yang diambil dari unsur-unsur film terutama dari dialog.

\section{Gosip dan Fitnah}

Secara umum, gosip adalah membicarakan sesuatu mengenai pihak ketiga baik positif maupun negatif tanpa kehadirannya sehingga pihak yang dibicarakan tidak dapat mengonfirmasi kebenaran dari pembicaraan tersebut. Gosip dipandang negatif dalam agama karena sering kali membicarakan aib orang lain. Gosip rawan menjadi fitnah karena seringkali ditambahi berbagai asumsi yang tidak benar yang merupakan dosa besar dalam ajaran agama Islam. Pada tataran denotatif, latar belakang keagamaan dari para pemeran film "Tilik" digambarkan secara menonjol karena karakter perempuan dalam truk tersebut kesemuanya memakai jilbab yang menunjukkan ketaatan pada ajaran Islam untuk menutup aurat (Gambar 1). Dalam film juga diperlihatkan bahwa dalam perjalanan ke rumah sakit mereka menyempatkan berhenti untuk salat. Pembacaan konotatif gambaran tersebut adalah bahwa karakter para perempuan berjilbab mewakili standar moralitas dari masyarakat secara umum sehingga memiliki otoritas untuk memberi penilaian pada baik-buruk perilaku warga masyarakat yang lain. Namun, dalam film ini diperlihatkan juga kontradiksi bahwa tidak semua perempuan tersebut taat pada aturan agama soal membicarakan aib orang lain dan juga fitnah. Secara konotatif, dapat dibaca bahwa walaupun terdapat nilai-nilai seragam yang dianggap mulia dan secara sepintas dianggap telah diterima oleh seluruh masyarakat, seringkali ketaatan, yang ditandai dengan pakaian dan ritual ibadah tersebut hanya pada kulit luar saja. Jika ditelisik lebih dalam, terdapat dinamika dan cara pandang beragam yang terkadang penuh pertentangan dalam tataran individual.

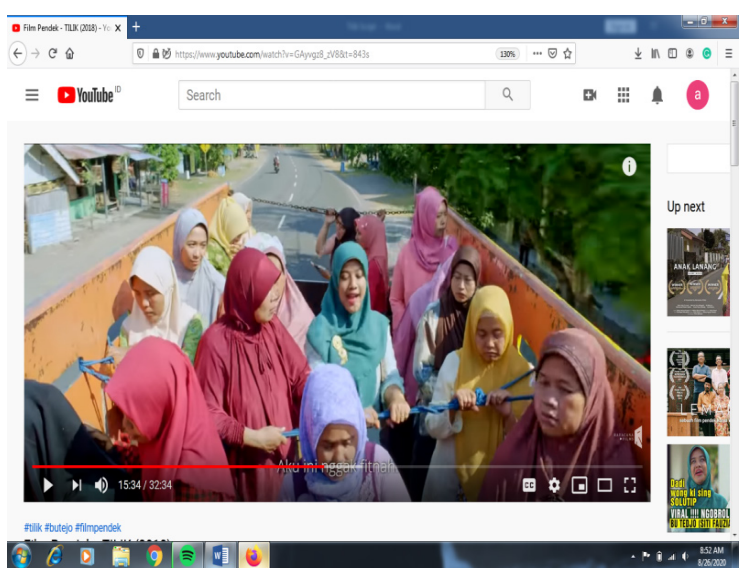

Gambar 1 Ibu-ibu menumpang truk bak terbuka. Film “Tilik”:15.34.

Penggambaran bahwa kegiatan bergosip adalah sesuatu yang buruk dipertegas pula dengan akting tokoh utama $\mathrm{Bu}$ Tejo yang memperlihatkan mimik mengejek dan nyinyir secara terbuka hingga terkesan karikatural. Dua tokoh lainnya, yakni Yu Nam dan Bu Tri, secara terbuka mengkritik perilaku $\mathrm{Bu}$ Tejo yang gemar membicarakan keburukan orang lain, seperti dapat dilihat dalam kutipan berikut (diambil dari subtitle berbahasa Indonesia dalam film):

Yu Nam: "Iya bener tuh kata Yu Ning. Eh Bu Tejo, fitnah itu lebih kejam dari pembunuhan" ("Tilik": 15.32).

Yu Ning: "Tapi ya nggak kayak gitu lah, Bu. Kalau berita tentang Dian itu tadi ternyata nggak kayak yang diomongin Bu Tejo tadi. Apa itu bukan fitnah namanya? Fitnah itu dosa besar, Bu"(“Tilik": 15.32).

Selain itu, Bu Tejo sendiri menunjukkan sikap marah ketika Yu Ning mengatakan hal buruk mengenai sumber harta suaminya. Yu Ning 
memprotes sikap Bu Tejo yang suka membicarakan keburukan orang lain, tetapi tidak terima ketika ia diperlakukan demikian. Bedanya, tokoh Dian yang dibicarakan tidak dapat membela dirinya. Namun, terlepas dari peringatan kedua temannya tersebut, $\mathrm{Bu}$ Tejo menyanggah bahwa apa yang dikatakannya bukanlah fitnah karena banyak warga kampung yang juga membicarakan soal Dian, serta bahwa yang ia sampaikan hanyalah informasi semata supaya warga lebih awas.

Bu Tejo: "Aku ini nggak fitnah. Aku cuma pengen jaga-jaga saja. Jaga-jaga kalau Dian itu sebenarnya emang perempuan nakal. Tukang ngegodain suami-suami kita" (“Tilik": 15.34).

Bu Tejo: "Trus ketika aku pengen ngasih informasi soal Dian, apa aku ini salah" (“Tilik": 19.44).

Tokoh lain, Bu Tri, berpendapat bahwa apa yang dilakukan $\mathrm{Bu}$ Tejo itu baik dan berguna.

Bu Tri: "Ya nggak lah Bu Tejo, kamu bener kok. Kalau menurutku Bu Tejo informasi tentang Dian itu berguna. Sekarang gini ya, Bu Tejo. Kalau hidupnya Dian berantakan, itu kan masalahnya dia sendiri, yang penting jangan sampai ngerusak keluarga kita" ("Tilik": 19.49).

Hal ini bukanlah tidak berdasar. Menurut Dunbar (2004), salah satu fungsi dari pengunaan bahasa adalah sebagai pengikat kelompok sosial. Gosip menyediakan informasi tentang individuindividu dalam masyarakat yang membantu individu lain untuk mencari sekutu, memetakan pesaing, dan mengawasi mereka yang bertindak tidak sesuai norma. Sementara itu, Foster (2004) dalam Meinarno dkk., (2011) menambahkan bahwa fungsi lain dari gosip adalah sebagai sarana hiburan dan sarana untuk memengaruhi anggota masyarakat lain untuk menjaga nilai-nilai bersama.

"Tilik" mengakomodasi kedua pandangan bahwa gosip itu buruk dan bertentangan dengan agama, tetapi juga tidak dapat dikatakan sebagai sesuatu yang benar-benar omong kosong. Terlebih di bagian akhir film, tampak Dian memasuki sebuah mobil dan terlibat pembicaraan yang memperlihatkan hubungan asmara dengan seorang lelaki paruh baya. Lelaki itu kemudian diketahui sebagai mantan suami dari Bu Lurah, ayah dari Fikri yang digosipkan $\mathrm{Bu}$ Tejo sebagai kekasih Dian. Walaupun dari film diketahui bahwa Bu Lurah dan Ayah Fikri telah berpisah, secara konotatif, adegan ini memberikan kesan bahwa sebagian gosip dari ibu-ibu tersebut dapat terindikasi benar. Dari perbincangan ibu-ibu di atas truk, Dian diberi kesan buruk karena tidak biasa bagi seorang gadis muda dan cantik yang menjadi pujaan banyak pria untuk berhubungan dengan pria yang seusia ayahnya. Akhir film ini seakan-akan memperkuat pandangan bahwa "gosip adalah fakta yang tertunda" sebuah slogan yang cukup populer yang dibawakan sebuah akun gosip besar di media sosial "Lambe Turah".

Selain itu, "Tilik" juga menggambarkan kekalahan tokoh Yu Ning. Ia yang sepanjang cerita tidak menyetujui $\mathrm{Bu}$ Tejo dan senantiasa berprasangka baik pada Dian serta tidak segan-segan berargumen keras untuk menangkis asumsi buruk $\mathrm{Bu}$ Tejo, justru jatuh kredibilitasnya. Saat tiba di rumah sakit ternyata rombongan tidak dapat bertemu Bu Lurah karena Bu Lurah sedang berada di UGD. Yu Ning yang sedari awal mengatur perjalanan tilik tersebut dianggap gagal berkoordinasi. Di akhir cerita, Bu Tejo justru tampil sebagai "pahlawan" karena ia berinisiatif untuk mengajak ibu-ibu mampir ke Pasar Beringharjo untuk menghibur rombongan ibu-ibu agar perjalanan ke kota tersebut tidak sepenuhnya sia-sia. Kekalahan Yu Ning yang membenci gosip dan menekankan prasangka baik diperlihatkan dengan pengambilan gambar jarak dekat yang fokus pada ekspresi sedih Yu Ning, ditambah latar musik yang sendu.

Penggambaran adegan ini sesungguhnya menunjukkan simpati dan keberpihakan film kepada tokoh Yu Ning. Namun, di sisi lain juga menekankan bahwa prasangka baik dan niat baik seringkali tidak mendatangkan kenyataan yang sesuai dengan harapan. Ia tetap kalah dari tokoh $\mathrm{Bu}$ Tejo yang lebih populer dan "berkuasa". 


\section{Hoaks dan Internet}

Film "Tilik" juga menggambarkan bagaimana masyarakat menanggapi informasi yang mereka dapatkan dari internet. $\mathrm{Bu}$ Tejo menjadikan informasi dari internet berupa gambar-gambar Dian di Facebook dan komen orang-orang sebagai sebuah kebenaran. Internet adalah sumber informasi yang aktual dan tepercaya. Orang harus melek internet agar tidak miskin informasi.

$\mathrm{Bu}$ Tejo: "Rajin-rajin baca berita dari internet donk, iya nggak. Biar kalau diajak ngomong itu nyambung gitu lho"(“Tilik": 4.47).

Bu Tejo: "Kok masih ngeyel sih. Informasi dari internet itu konkret, ada fotonya, ada gambarnya. Aku ulangi sekali lagi ya, Yu Ning. Aku ini cuma pengen jaga-jaga aja!" (“Tilik": 21.10).

Tokoh Yu Ning adalah satu-satunya yang menunjukkan resistansi terhadap asumsi Bu Tejo.

Yu Ning: "Tapi semuanya belum tentu benar lho Bu Tejo. Berita dari internet itu harus dicek dulu. Nggak cuma ditelan mentah-mentah. Inget nggak warga desa kita dulu pernah ada yang ketipu obat herbal yang diiklankan di internet lho. Bener lho itu. Siapa yang pernah ketipu? Kamu pernah ketipu Yu?" ("Tilik": 4.58)

Walau dialog dalam film tentang kepercayaan mutlak terhadap informasi yang beredar di internet terdengar sangat naif, hal tersebut adalah sebagai sesuatu yang banyak terjadi. Fenomena hoaks, disinformasi, dan fitnah sangat lumrah terjadi terutama di kalangan masyarakat yang tidak melek dan kritis. Hal ini bertambah parah justru ketika disebarkan oleh mereka yang memiliki pengaruh. Dalam panggung truk terbuka film "Tilik", hal tersebut direpresentasikan oleh tokoh Bu Tejo yang merupakan tokoh yang sangat dominan. Dalam kontestasi narasi misalnya, Bu Tejo muncul sebagai tokoh yang melempar isu, memonopoli informasi dan percakapan. Sementara tokoh lainnya hanya sekadar menimpali. Jika terdapat bantahan seperti yang dilakukan Yu Ning, Bu Tejo mematahkannya dengan meragukan netralitas Yu Ning yang ternyata masih saudara jauh Dian, selain dalih melindungi warga dari perempuan pengganggu perkawinan yang didukung Yu Nam dan Bu Tri.

Selain itu, dari percakapan diketahui bahwa tokoh $\mathrm{Bu}$ Tejo adalah istri dari seorang pemborong sukses.

$\mathrm{Bu}$ Tejo: “Mentang-mentang sekarang udah jadi pemborong sukses, temenannya sama pejabat terus sekarang banyak diomongin yang nggakngak" ("Tilik": 18.59).

Pesan bahwa $\mathrm{Bu}$ Tejo memiliki posisi yang tinggi secara ekonomi ini secara simbolis diperkuat dengan banyaknya perhiasan yang dipakai $\mathrm{Bu}$ Tejo dibandingkan pemeran perempuan lain. Dalam adegan di dalam truk, Bu Tejo seringkali diposisikan di tengah truk, dikelilingi oleh perempuanperempuan lainnya, yang semakin membuat penggambaran $\mathrm{Bu}$ Tejo sebagai tokoh sentral semakin menonjol (Bu Tejo memakai pakaian biru pada gambar 1).

Penggambaran kepercayaan utuh para karakter dalam film terhadap internet yang tampak tidak rasional sejatinya adalah bentuk sindiran dari film "Tilik" mengenai apa yang terjadi dalam masyarakat. Hal ini dikonfirmasi dalam wawancara dengan penulis naskah (Damarjati, 2020).

\section{Perempuan}

Tema utama yang tidak terbantahkan dari film "Tilik" adalah perempuan. Para perempuan pelaku kegiatan bergosip tersebut adalah perempuan yang sudah menikah. Film ini menguatkan stereotip perempuan yang gemar bergosip tentang kehidupan pribadi orang lain. Walaupun tidak mengetahui pekerjaan pasti dari tokoh Dian, ketika Dian yang baru bekerja terlihat mengenakan barang-barang mahal, muncullah asumsi-asumsi bahwa Dian melakukan pekerjaan yang "tidak benar". Frase ini, ketika dikenakan kepada seorang perempuan terutama akan mengacu pada eksploitasi tubuh dan sensualitasnya. Hal tersebut terlihat dari percakapan Bu Tejo berikut:

$\mathrm{Bu}$ Tejo: "Makanya sekarang coba kalian pikir. Aku bukannya mau ngeremehin keluarga Dian lho ya. Jelas dari kecilnya Dian itu ditinggal minggat sama bapaknya. Ibunya juga punya 
sawah segitu doang. Makanya dia lulus SMA nggak kuliah. Baru aja kerja, Hpnya baru, motornya baru, iya kan? Uang dari mana coba?. Itu barang mahal semua lho. Kaya aku nggak tahu merek aja" (“Tilik": 3.52).

Di balik munculnya percakapan tersebut terdapat prasangka-prasangka yang muncul dari stereotip yang melatarinya bahwa perempuan tidak mampu untuk mengembangkan bakat dan potensinya untuk melakukan pekerjaan-pekerjaan publik. Modal terbesar perempuan adalah kemolekan tubuhnya. Ketika banyak laki-laki yang tertarik kepada tokoh Dian, ia digosipkan memakai susuk. Keberadaan seorang perempuan selalu dilihat berdasarkan relasinya dengan laki-laki. Hal ini semakin menguat karena tokoh Dian dibicarakan sering keluar masuk mal dan hotel bersama "omom".

Selain itu, Bu Tejo mengutarakan stereotip bahwa menjadi perempuan yang baik adalah perempuan yang menikah. Pada umur tertentu, perempuan haruslah sudah menikah. Jika pada umur tertentu ia belum menikah, perempuan tersebut dapat menjadi ancaman, bisa menggoda suami orang dan merusak rumah tangga. Padahal hubungan asmara sejatinya melibatkan konsensus bersama antara laki-laki dan perempuan. Lebih jauh lagi, Dian digosipkan hamil karena pernah terlihat muntah-muntah.

Akting nyinyir dan prasangka yang dikemukakan $\mathrm{Bu}$ Tejo sangat ditonjolkan dalam film. Sampai di sini khalayak yang menonton bisa menganggap bahwa film ini menyampaikan sindiran terhadap para perempuan yang suka bergosip seperti Bu Tejo. Di sisi lain, tokoh laki-laki dalam film ini digambarkan tidak suka bergosip. Hanya ada satu laki-laki dalam film yang terlibat, yakni Gotrek, sang supir truk. Saat mengemudi, Gotrek tampak ikut mendengarkan gosip di belakang truk. Walaupun tertarik dengan informasi tentang Dian, Gotrek enggan terlibat dalam argumentasi dan ikut bergosip. Ketika istri Gotrek menanyainya soal ekspresinya yang serius, Gotrek berkilah dan menyatakan "tidak apa-apa". Namun, dalam adegan lain terlihat bahwa ternyata Gotrek menyukai sosok Dian. Ia bahkan mencalonkan Dian sebagai calon lurah yang baru. Hal ini mengundang kemarahan istri Gotrek. Adegan tersebut seakan mengonfirmasi kebenaran asumsi Bu Tejo bahwa laki-laki mudah tergoda dengan sosok seperti Dian.

Sebuah adegan lainnya yang dilekatkan pada keperempuanan adalah ketika truk yang ditumpangi rombongan perempuan tersebut diberhentikan polisi karena melanggar aturan lalu lintas. Truk adalah alat angkut barang dan bukan untuk mengangkut penumpang. Para perempuan tersebut protes bahwa mereka melakukan itu dalam keadaan darurat dan memohon empati dan nurani pak polisi. Polisi yang seorang diri tersebut harus menghadapi rundungan, sanggahan, dan rayuan ibu-ibu tersebut. Mereka akhirnya bisa lolos, meninggalkan pak polisi dengan beberapa tas plastik buah dan penganan. Adegan tersebut juga sekaligus simbol betapa maraknya praktik suapmenyuap dan negosiasi dalam penegakan hukum di jalan raya. Para perempuan di sini digambarkan seolah-olah kebal hukum. Di sinilah kembali terlihat bahwa pandangan masyarakat yang patriarkis yang seringkali memandang bahwa perempuan sebagai makhluk lemah yang harus dilindungi (Mundayat, 2020), dipergunakan oleh $\mathrm{Bu}$ Tejo dan rombongan untuk berkelit dari kewajiban hukum. Lelaki yang baik harus memperlakukan perempuan dengan baik, melindungi dan mengayomi mereka, apalagi kepada para perempuan yang usianya melebihi usia polisi muda tersebut. Walaupun Bu Tejo mengancam akan melakukan kekerasan fisik, hal tersebut tidak dianggap sebagai hal yang serius, hanya ibu-ibu yang merajuk. Hal ini mungkin berbeda jika yang melakukan ancaman adalah laki-laki.

Bu Tejo: "Pokoknya Pak Polisi, kami mau jenguk Bu Lurah! Titik. Bapak kalau ngeyel, saya gigit aja, ya! Udah ayo Bu! Kita turun aja. Aku udah gemes banget. Mau digigit apa gimana?! Hah?! Jadi, orang itu yang peduli, lah!" ("Tilik": 23.05) 


\section{RESEPSI KHALAYAK}

Dalam teori resepsi (Hall, 1980), pemirsa bukanlah khalayak yang pasif menerima pesan begitu saja. Pemirsa berperan secara aktif dalam meginterpretasikan pesan-pesan yang mereka terima. Pemirsa bisa saja membaca kode-kode secara berbeda dari makna konotasi yang dimaksudkan pembuat film. Film "Tilik" menarik karena memancing berbagai pemaknaan dari khalayak. Perbedaan ini bahkan memancing perdebatan, pertikaian tajam, hingga perundungan di media sosial, berbagai tulisan pro dan kontra di media-media daring seperti Tirto, Mojok, dan GeoTimes, juga diskusi-diskusi akademis daring. Secara khusus, bagian ini akan lebih memfokuskan pada resepsi pengguna Twitter berdasarkan tiga posisi pembacaan yang ditawarkan Hall, pembahasan juga didukung analisis dari Drone Emprit yang didapatkan dari Fahmi (2020).

\section{Pemaknaan Dominan}

Pada pemaknaan dominan, pemirsa dapat menikmati film yang ditayangkan. Hal tersebut tentu menjadi tujuan pembuat film. Ini hanya bisa terjadi jika film dapat menyajikan cerita dan eksekusi sinematografi yang meyakinkan dan menarik. Meyakinkan artinya jalan cerita logis dan koheren, serta mereka dapat terhubung dengan apa yang dialami karakter. Banyak komentar dari pemirsa "Tilik" menyatakan bahwa mereka dapat becermin pada "Tilik" mengenai apa yang terjadi di masyarakat bahkan keluarga dan diri mereka sendiri. Pemaknaan dominan terutama terlihat dari apresiasi yang diberikan pemirsa terhadap film "Tilik".

Menurut Fahmi (2020), popularitas film ini dimulai dari beberapa cuitan yang mendapat atensi netizen, terutama akun-akun yang memang antusias terhadap film. Tren ini semakin viral ketika diramaikan dengan apresiasi dari akun-akun berpengaruh lainnya.

@TarizSolis: "Tilik perjalanan menjenguk Bu Lurah berlangsung ricuh saat Bu Tejo dan Yu Ning mulai berdebat soal Dian. Mengangkat topik soal bergunjing dan menyebar hoax, film pendek ini akan membuatmu terbahak sekaligus jengkel. Bu Tejo pancen jos!"'(19/08/20)

@hafilova: "Mau tau yg lebih bahaya ketimbang emak2 naik matic? Yap, emak2 noob internet bersatu julidin anak tetangga di bak truk. "Tilik" mjd 30 menit menyenangkan. Susah u/ ngga tersenyum ketika sutradara Wahyu Agung Prasetyo dgn cerdas main2 satir sosial bersama casting jempolan. 4/5." (18/08/20)

Selain itu, terdapat pula cuitan yang menjelaskan pelajaran yang dapat dipetik dari menonton "Tilik" dengan melihat penggambaran berbagai karakter dalam film.

@zenrs: “Dalam beberapa hal, "Tilik” malah lebih mencerminkan (orang2) Twitterland ketimbang desa/kampung: sotoy, reaktif pada isu/info, nyerocos, berisik, sibuk mendengar untuk menjawab dan bukan untuk memahami...."(22/08/20)

@henrysubiakto: "Film Tilik itu kritik sosial, yg gambarkan masy skrg, berpakaian agamis, rajin pengajian tp hobi ngrumpi, nyebar berita tdk jelas dr internet, dan nuduh2. Ini penyakit sosial yg dikritik film tsb. Karakter spt bu Tejo, Yu Ning dll itu bnyk tjd di masy, tak sll ibu2 tp jg laki2." (26/08/2020)

Dari pendapat-pendapat tersebut, terlihat bahwa sebagian besar khalayak dapat menerima dan mengonsumsi seluruh pesan yang disampaikan oleh film, baik praktik bergosip, isi gosip, lelucon, maupun alur cerita sebagai sesuatu yang meyakinkan. Ini tidak berarti mereka setuju dengan praktik tersebut, tetapi mereka menerima penggambaran yang dilakukan oleh film dan menganggapnya sebagai satir atau kritik sosial. Di sisi lain, pembacaan dominan dalam film "Tilik" dapat juga berupa persetujuan atas tindakan para tokoh, yakni persetujuan akan pesan denotatif film seperti yang dinyatakan@hikariyoukai berikut:

@hikariyoukai: "Nonton Tilik adalah semacam pembuktian kata2 Mbak Taylor Swift "the rumor are terrible and cruel but honey most are them are true " (22/08/20) 
Pembacaan dominan lainnya tidak melihat ada yang salah dalam penggambaran film tentang tokoh Dian. Dian dianggap tidak melakukan hal yang salah sebab ia menjalin asmara secara serius dengan seorang duda yang telah lama bercerai dan bukan suami orang. Sementara beberapa pemirsa setuju pada penggambaran dalam film karena hal itu menunjukkan realitas yang tidak hitam-putih, seperti yang disampaikan@mrshananto berikut: @mrshananto: “Aku setuju Sof. Kok selesai film aku malah ketawa. Rasain. Hidup mmg gak hitam putih. Kesel bgt iya. Tp bukankah hidup kadang begitu? Kl mau hitam putih ya nonton yg versi propaganda macam G30S/PKI." (22/02/20)

\section{Pemaknaan Oposisional}

Dalam pemaknaan oposisional pemirsa menolak mengonsumsi apa yang direpresentasikan oleh film karena bertentangan dengan nilai-nilai yang dianut. Pemaknaan oposisional terbesar dari film "Tilik" terutama datang dari perspektif feminis. @RoryAsyari dengan tajam mengatakan, Materi edukatif film ini nol, nihil, sетиa soal prejudice, fitnah, stigmatisasi perempuan, dan kemenangan hoax maker (22/08/20). Hal ini karena tokoh perempuan bijak yang mengkritik justru dikalahkan, padahal Indonesia saat ini sedang darurat literasi digital. Hal tersebut dapat dilihat dari cuitan-cuitan dengan likes/suka banyak berikut:

@FaizaMardz: "Film TILIK itu memang mencerminkan realitas KITA (Indonesia): Realitas di mana masyarakat yang patriarkis dan misoginis, suka menstereotipkan perempuan. Menghakimi perempuan, menghukumnya dengan berbagai label/ stigma. Coba Anda semua cek. Film kacamata laki doyan melanggengkannya!" (22/08/20)

@sihirperempuan: "Saya tidak perlu menambahkan kritik feminis thd film TILIK, yang sudah sgt baik disampaikan teman2. TILIK sebaiknya tidak dilihat sebagai masalah tunggal, tapi gejala fenomena yang lebih besar: absennya perspektif feminis dlm metode berkarya, juga dalam medan produksi kebudayaan" $(23 / 08 / 20)$
Dalam pandangan oposisional, film "Tilik" hanya menggambarkan sisi negatif dari perempuan yang sesuai dengan stereotip yang sudah ada di masyarakat. Menurut mereka, untuk dapat lebih edukatif, harus ada unsur-unsur kritik eksplisit yang dimasukkan dalam film misalnya film ini dapat memasukkan tokoh lelaki yang juga ikut bergosip karena kenyataan di lapangan bahwa bergosip tidak melulu monopoli perempuan. Selain itu, porsi besar dapat diberikan kepada tokoh Dian untuk menjelaskan dirinya dan diberi lebih banyak agensi. Kritik juga menekankan bahwa representasi dalam film "Tilik" menggambarkan sudut pandang pembuat film yang patriarkis seperti yang disampaikan@FaizaMardz.

Dalam hal ini,@mardiasih menyatakan bahwa terdapat pula tokoh feminis dalam film ini, yakni Yu Ning. Ia berani berkonfrontasi dengan Bu Tejo yang lebih berkuasa dan teguh pada pendiriannya. Walaupun demikian, banyak juga cuitan yang mengatakan bahwa Yu Ning tidak sepenuhnya digambarkan sebagai perempuan yang rasional. Pada suatu adegan, Yu Ning menuduh bahwa truk mereka mogok karena uang yang diberi Bu Tejo kepada Gotrek, supir truk, adalah uang yang tidak berkah. Selain itu, dalam melakukan perlawanan terhadap Bu Tejo, ada bias dari Yu Ning yang ternyata saudara jauh Dian. Beberapa komentar lain menyukai penggambaran $\mathrm{Bu}$ Tejo dalam mengungkap sisi positif dari karakter tersebut.

Dari analisis Drone Emprit dalam Fahmi (2020), cuitan yang mengapresiasi film "Tilik" jauh lebih banyak daripada yang mengkritisi. Ini artinya bahwa pembacaan dominan lebih banyak daripada oposisional. Hal ini tentu menjadi kunci kesuksesan film ini, yakni narasi bahwa film "Tilik" menggambarkan realitas sosial masyarakat.

Pelecehan dan stigmatisasi terhadap perempuan yang terbalut dalam candaan atau humor menurut Parrott \& Hopp, (2020) sangat sering terjadi dan susah untuk dikritisi karena persepsi bahwa humor seharusnya tidak ditanggapi dengan serius dan tujuan humor adalah untuk menghibur belaka. Humor yang seksis justru menjadi lebih dapat 
diterima ketika hal tersebut dilakukan perempuan. Hal ini juga disuarakan oleh @FaizaMardz yang sesuai dengan teori representasi.

@ FaizaMardz: "Siapa bilang film itu menghibur (saja!) Setiap angle kamera yang dipilih pun adalah keputusan "politik"! Judul yang dipilih adalah keputusan politik. Setiap elemen yang dipilih adalah keputusan politik. Cast/akting yg dipilih keputusan politik. Feminis sangat sensitif melihat." (22/08/20)

\section{Pemaknaan Negosiatif}

Di antara perdebatan runcing antara pemaknaan dominan dan pemaknaan oposisional terhadap film "Tilik", terdapat pula mereka yang berada di tengah-tengah, yakni mereka yang dapat menerima apa yang diproduksi film, tetapi juga menerima adanya pemaknaan berbeda. Dalam kasus film "Tilik" hal ini disuarakan oleh cuitan berbalut humor@FiersaBesari yang mendapatkan21,9 ribu suka dan dari sutradara Joko Anwar, @jokoanwar yang mendapat 23,9 ribu suka. Suara negosiatif yang menerima perbedaan pendapat, walau lebih condong ke pemaknaan dominan pada film "Tilik" ini, justru mendapat respons postif terbanyak dari netizen jika dilihat dari jumlah suka.

@FiersaBesari: Kesimpulan setelah menonton Tilik: 1. Plot twist sebenarnya ada di Dian 2. Kemungkinan nama gadis Bu Tejo adalah Surti. Because Surti Tejo wqwq 3. Karya yang baik bukan hanya dipuji, tapi juga diperdebatkan. Tilik berhasil menjadi karya baik 4. Tilik dapat berarti "tea leak" (23/08/20)

@jokoanwar: "Seingat saya, baru kali ini ada film pendek mengundang begitu besar perhatian, diskusi serta perdebatan yang sangat ramai dan menarik di Indonesia. Ini saja sudah satu pencapaian besar buat film TILIK. Great job, buat kru dan pemain. Salut dan selamat!" $(22 / 08 / 20)$

\section{SIMPULAN}

Tulisan ini telah membahas bagaimana pesan-pesan terutama gosip, fitnah, internet, dan perempuan direpresentasikan dalam film melalui dialog, plot, dan kode-kode semiotik lainnya. Pesan-pesan yang dibawakan oleh pembuat "Tilik" kepada khalayak dapat pula dimaknai oleh khalayak secara berbeda. Resepsi khalayak akan menentukan apakah film tersebut berhasil atau tidak. Secara umum "Tilik" dimaknai dalam kerangka pemaknaan dominan, artinya pemirsa memvalidasi atau setuju akan representasi yang ditampilkan dalam film. Pembacaan dominan dapat berupa persetujuan pada pesan denotatif dan konotatif, misalnya film ini dimaknai sebagai kritik sosial yang segar. Hal inilah yang menandai kesuksesan film "Tilik". Namun, perspektif dan nilai-nilai pemirsa yang lain akan menimbulkan pemaknaan yang berbeda, dalam kasus "Tilik" adalah kritik feminis akan pemakaian kacamata patriarki dalam produksi film, selain pesan film mengenai gosip dan hoaks. Di sisi lain, pembacaan negosiatif terutama yang disampaikan kepada khalayak penting untuk menjembatani kedua posisi pemirsa. Dengan demikian, dapat terjadi diskusi yang membawa ke arah saling pengertian dan pemahaman akan perbedaan sudut pandang terutama untuk dapat terus- menerus membongkar stereotip-stereotip yang tidak disadari ada di masyarakat yang direkonstruksi media.

\section{KEPUSTAKAAN}

Agistian, F., \& Ruth Mei Ulina, M. (2018). Pornografi dalam Film: Analisis Resepsi Film "Men, Women \& Children." ProTV, 2(1), 1935.

Barthes, R. (1998). The Semiotics Challenge. New York: Hill and Wang.

Damarjati, T. (2020, August 22). Viral, Tradisi Tilik Naik Truk Warga Dlingo Diangkat Film. Retrieved from https://jogja.idntimes.com/ hype/entertainment/tunggul-damarjati/viraltradisi-tilik-naik-truk-warga-dlingo-diangkatfilm $/ 6$

Dunbar, R. I. M. (2004). Gossip in Evolutionary Perspective. Review of General Psychology, 8(2), 100-110. https://doi.org/10.1037/10892680.8.2.100 
Fahmi, I. (2020). Tilik (2018).

Hall, S. (1980). Encoding/decoding. In S. Hall (Ed.), Culture, Media, Language. London: Routledge.

Hall, S. (1997). The work of representation. In S. Hall (Ed.), Representation: Cultural representation and Signifying Practices (pp. 13-74). London: Sage Publication \& Open University.

I. Handayani, Lukmantoro, T., \& Naryoso, A. (2013). Representasi Persahabatan dalam Film $5 \mathrm{~cm}$. Interaksi Online, 1(4).

Jogja, P. (2020). Dunia Hoaks di Kepala Bagus "Bacep" Sumartono, Penulis Naskah Film "Tilik."

Langga, F. H., Ahmad, H. A., \& Mansoor, A. Z. (2020). Representasi Islami dalam animasi "Nussa" sebagai media pembelajaran untuk anak. Rekam, 16(2). https://doi.org/10.24821/ rekam.v16i2.3612

Manesah, D. (2016). Representasi Perjuangan Hidup dalam Film "Anak Sasada" Sutradara Ponty Gea. Jurnal Proporsi, 1(2), 179-189.

Meinarno, E. A., Bagaskara, S., \& Rosalina, M. P. K. (2011). Apakah Gosip Bisa menjadi Kontrol Sosial. Jurnal Psikologi Pitutur, 1(2), 78-85.

Mundayat, A. (2020). Antropologi Ghibah: Mulut Bu TejoMulut Kita.

Parrott, S., \& Hopp, T. (2020). Reasons people enjoy sexist humor and accept it as inoffensive. Atlantic Journal of Communication, 28(2), 115-124. https://doi.org/10.1080/15456870.2 019.1616737

Pertiwi, M., Ri'aeni, I., \& Yusron, A. (2020). Analisis Resepsi Interpretasi Penonton terhadap Konflik Keluarga dalam Film "Dua Garis Biru." Jurnal Audiens, 1(1). https://doi. org/10.18196/ja.1101

Rokhani, U., Salam, A., \& Rochani-Adi, I. (2016). Rekonstruksi Identitas Ke-“Tionghoa"-an dalam Film Indie Pasca-Suharto. REKAM: Jurnal Fotografi, Televisi, Animasi, 12(1), 55. https://doi.org/10.24821/rekam.v12i1.1380

Suharso, P. (2019). Pemanfaatan Drone Emprit dalam Melihat Trend PerkembanganBacaan Digital melalui Akun Twitter. ANUVA, 3(4), 334-346.
Wahyuni E, T. R. (2020). Analisis pesan perdamaian pada film "Cahaya dari Timur (Beta Maluku)": Pendekatan semiotika Roland Barthes. Rekam, 16(2), 115-124. https://doi.org/10.24821/ rekam.v16i2.4248

Widiyatmika, W., Sulistyo, E. T., \& Nugroho, S. (2019). Nilai Pendidikan Karakter Pada Film Sang Kiai. Mudra Jurnal Seni Budaya, 34(1), 73-79. https://doi.org/10.31091/mudra.v34i1 
